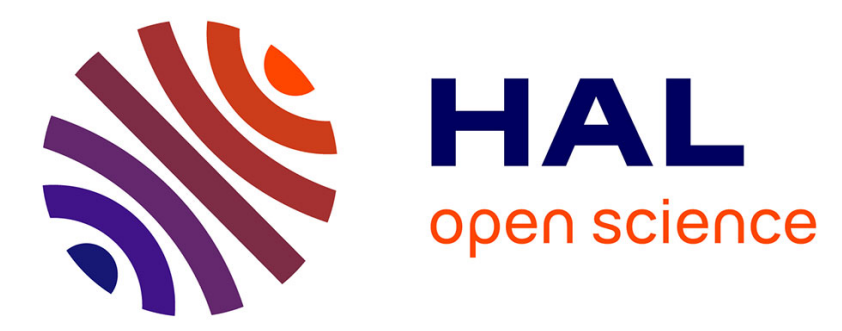

\title{
Cities in the Italian political system: incomplete actors and objects of policies
}

Francesca Artioli

\section{To cite this version:}

Francesca Artioli. Cities in the Italian political system: incomplete actors and objects of policies . Cities as Political Objects. Historical Evolution, Analytical Categorisations and Institutional Challenges of Metropolitanisation , Edward Elgar Publishing, pp.135 - 155, 2016, 9781784719890. halshs-01562551

\section{HAL Id: halshs-01562551 \\ https://shs.hal.science/halshs-01562551}

Submitted on 27 Jul 2017

HAL is a multi-disciplinary open access archive for the deposit and dissemination of scientific research documents, whether they are published or not. The documents may come from teaching and research institutions in France or abroad, or from public or private research centers.
L'archive ouverte pluridisciplinaire HAL, est destinée au dépôt et à la diffusion de documents scientifiques de niveau recherche, publiés ou non, émanant des établissements d'enseignement et de recherche français ou étrangers, des laboratoires publics ou privés. 


\section{Published as}

Francesca Artioli. Cities in the Italian political system: incomplete actors and objects of policies. Cities as Political Objects. Historical Evolution, Analytical Categorisations and Institutional Challenges of Metropolitanisation (edited by Alistair Cole and Renaud Payre), Edward Elgar Publishing, 2016, 135 - 155

$\langle$ http://www.e-elgar.com/shop/cities-as-political-objects $\rangle$

\section{Chapter Seven}

\section{Cities in the Italian political system: incomplete actors and objects of policies}

The Italian urban system is polycentric and, at the same time, dominated by two main cities, Rome and Milan. In this respect, the urban question in Italy differs from the United Kingdom and France, where the most relevant economic, cultural and political functions are concentrated in a single city which is the national capital (London and Paris), but it also differs from the German case, structured by a series of metropolises having complementary functions. The government of cities and of this polycentric system is therefore a crucial issue in the Italian political system.

In Italy, the municipal level has historically been highly relevant for the representation of territorial identities and interests. Several cities existed as relatively autonomous political systems until the $16^{\text {th }}$ century and, in some cases, the $19^{\text {th }}$ century. Indeed, national unification took place later than in most other European countries. In addition, the capacity of the central state to penetrate and homogenize subnational territories has been incomplete (Cassese, 2014; Romanelli, 1995), and strong localism is still a relevant feature of the Italian political system.

This chapter examines the transformation of urban policies in Italy since the end of the Second World War. By urban policies, it refers to the construction of the city as a political actor and to the identification of the city as a particular object for policies. It shows that a long-term trend seeking to strengthen both urban political authorities and the relevance of the urban question as a specific policy problem has been punctuated by turnarounds and failures. Urban policies have experienced, and still experience, problems of coordination, effectiveness, resources and legitimacy. Italian cities often change without and beyond public policies. This unsolved urban question in Italy has to be understood considering the ongoing confrontation between the functioning of a state with a centralizing original structure but limited effectiveness and pressures to invent responses to both democratic challenges and urban problems. 
The chapter focuses first on the process of redistribution of competencies and responsibilities that have taken place in the originally centralised Italian political system over the last 25 years and identifies its effect on city governments. It then moves to the analyses of the transformation of the city as an object of policies in both the national and the urban agendas. Finally, it points out the limits of urban policies in their capacity to govern changing Italian cities.

\section{Competencies and differentiation of city governments}

Following unification, the Italian political and administrative system was organised along Napoleonic lines (see below). Over the past 150 years, the history of the Italian unitary state has been characterized both by the growth of local government competencies and by the recognition of the specific challenges faced by cities. Far from being straightforward, these processes have been structured by continuous tensions between state centralization and local autonomy, on the one hand, and between undifferentiated subnational governments and the specificity of urban problems, on the other hand.

\section{The transformation of a centralised state}

At its creation in 1861, the newly born Italian state was established as a centralized state, by putting aside the federalist option sought by a segment of the cultural and political elites (Aimo, 1997; Romanelli, 1995). The unification process took the shape of an expansion war undertaken by the Savoy monarchy and conducted against the Church and other pre-unitary states. In this context of "unification by conquest" (Piattoni \& Brunazzo, 2010), the choice of a centralised system was conceived as the most suitable response to centrifugal pressures coming from the annexed territories, which were also characterized by huge differences in terms of their political organisation, administrative systems and economic development.

The adopted system for local governments was similar to the Napoleonic model. Beside the fact that this was a two-tier system (communes and province, echoing the communes and départements of the French model), it also shared with this model some fundamental features that have shaped the government of cities in the long run. One was the limited formal competencies and autonomy of municipal governments in the elaboration of policies and the provision of services. Competencies were narrow, local resources attributed by the central state and local policies submitted to control from the state. A second defining original feature was the legal uniformity of municipalities. Municipal powers were undifferentiated, independently of the size, or the social and geographical characteristics of 
the city, which created, until the recent reform, a long-term divergence between legal uniformity and real-world territorial diversity.

After the end of the Fascist regime and with the replacement of the Monarchy by a Republican regime local elections were re-established. Although local autonomy was recognized in the new Constitution, the centralized solution adopted in 1861 was fundamentally left unchanged (Vandelli, 2013). Despite the fact that regions were established by the 1948 Constitution, they were not actually created until $1970^{1}$ and lacked substantial autonomy until the 1990s. The main obstacle to the establishment of regional governments came from opposed views from the DC (the Christian Democrats) and the PCI (the Communist Party) over regionalism. Because of the ongoing exclusion of the PCI from government at the national level, the latter became increasingly committed to regionalization that started to be conceived as a manner for taking control of some administrations. Conversely, the DC and its smallest allies saw the centralist option as a protection for their power. As a result, territorial cleavages remained quiescent for decades (Amoretti, 2004; Piattoni and Brunazzo, 2010). Therefore, from the end of the World War II until the decentralizing reforms of the 1990s, Italian city governments (and subnational governments in general) were weak, and they mainly relied on local political ties for accessing the centre and getting resources. In this respect, Italy is similar to other Southern European centralized countries, and contrasts with stronger forms of local autonomy in Northern Europe (Page \& Goldsmith, 1987).

Relevant reforms aimed at reorganizing the distribution of competences and responsibilities between levels of governments were introduced in 1990. They concerned all the three tiers of subnational governments (municipalities, provinces and regions) and refashioned the initial centralized feature of the Italian state. However, the process of reforms took nonlinear pathways and responded to different priorities, which were evolving over time. Legislative outputs were the product of agreements between stakeholders competing on both a partisan dimension and a territorial one. The latter dimension included the activation of the north/south territorial cleavage and its translation into consensus and votes by the Northern League since the end of the 1980s, but also the competition between different subnational levels of governments (mainly regions and cities) about winners and losers of the processes of reform. As a result of these composite conflicts, subnational governments were reorganized through fragmented initiatives. Reforms constitute a flow of both governmental and parliamentary actions that addressed both the whole system of territorial powers or specific policy sectors and levels of government. As a result, this period of almost 25 years of reforms has been described as a process of layering, in which each change has produced partially unsatisfactory results and, thereafter, settled the bases for a new change (Lippi, 2014, p. 499).

\footnotetext{
${ }^{1}$ With the exception of the five special status regions for the two islands of Sicily and Sardinia and the border and multi-lingual regions of Val d'Aosta, Trentino Alto Adige and Friuli Venezia Giulia.
} 
Andrea Lippi distinguishes three waves in this decentralization/devolution project. The first started at the beginning of 1990 and ended in 2001. This first cycle was inspired by NPM principles, such as efficiency, performance evaluation and cost-recovery, and by the principles of vertical subsidiarity and horizontal subsidiarity fostered by the EU. It was strongly sustained by the reformist project of the centre left majority that ruled Italy between 1996 and 2001. It closed with a Single Act that consolidated all the legislative changes approved during the previous decade (2000) and the constitutional reform that formalized the regionalized feature of the state (2001). The issue of regional devolution structured the second wave of reforms, from the beginning of the 2000 to the financial crises of 2008 . Indeed, the right-wing coalition in power during the 2000s attempted - and failed - to introduce a number of federalist reforms. Devolution was strongly supported by the Northern League, but also opposed by other parts of the center right majority, being ideologically centralist. The result of second period is what has been called a quasi-federalist (Lippi, 2011) or a semi-federalist state (Brunazzo, 2010). The third and last wave opened with the 2008 crises. Here, measures were dominated by the reduction of public expenditure and by the so-called reduction of the "costs of politics", the latter being the costs of elective representatives of the three levels of subnational governments (Dente, 2012). A series of financial laws and decrees defined spending cuts and restrictions, reduced subnational governments' room of manoeuvre, while making their governments more "responsible" in the management of decreasing resources. Because of an increased control of the state over public resources, this period has been interpreted as implying a recentralization of the previous decentralizing trend (Bolgherini, 2014; Dente, 2012; Di Mascio \& Natalini, 2014).

\section{Empowering cities, inventing the metropolis}

What were the main consequences of these reforms for cities as political actors and as the objects of policies? Four points can be underlined. Roughly speaking, these waves of reforms have had the overall effect of empowering municipal governments and increasing their autonomy, despite their differences and despite a swinging pendulum in the crucial issue of city financial resources (see below). From the 1990s onward, central state controls over local authority acts have been abolished, administrative senior executives (segretari municipali) are no longer state civil servants and municipalites can each define their charter. Furthermore, in application of the principle of subsidiarity, municipalities have gained decision-making autonomy over a range of policies delegated to them by the regions. Similarly, measures have been undertaken for facilitating contractual agreements between municipalities and other public and private actors (Bobbio, 2000).

Secondly, these reforms were not only aimed at transforming the legal and administrative framework for policies, but they were also deeply anchored to the idea of reforming Italian democracy. When the decentralizing cycle opened at the beginning of the 1990s, national politics was afflicted by scandals, and the established partisan system - which used to play a crucial role in political competition, as well as in distributing resources in the post-war 
period - was disrupted. Hence, a change in electoral rules was seen as one of the remedies for a "sick" Italian democracy. In opposition with the centre, local democracy beyond parties was equally seen as a starting point for renewal. At its beginnings, this reformist project for urban government was sustained by members of the political elite who were elected mayors during the hectic years of the early 1990s. These new elected mayors presented themselves as either outsiders or reformers of the dominant parties from within (Pinson et al., 2013). At the institutional level, the direct election of mayors, using a twoballot majority system, was introduced in 1993. It replaced a system where the mayor was designed by municipal councils and which was strongly controlled by political parties and their changing coalitions. By introducing direct election, the new municipal system strengthened mayor autonomy, empowered the municipal executive formed by the mayors and its deputies, and fostered mayoral legitimacy vis-à-vis both the municipal council and the local electorate (Baldini, 2007; Vandelli, 1997). From both political and institutional standpoints, this movement favoring cities was opposed by the Northern League as contradictory with its devolutionist goals (Pinson et al., 2013).

Thirdly, the metropolitan question has arisen as an issue to be tackled through reorganisation and differentiation of subnational governments. As it often happens, Italian municipal borders do not coincide with functional metropolitan areas of the country's biggest cities. Since 1990, there have been several attempts to create a new kind of metropolitan government. In 1990 the possibility to create a città metropolitana was introduced for the biggest cities of the country; this new government should be created in a "bottom-up" manner, through agreements between regions and concerned provinces and municipalities. Despite the fact that no single example of such a metropolitan government was created, ten years later (2001) the existence of this political and administrative entity was inscribed in the constitution, a choice that fits within the broader reform of subnational governments implemented by the centre-left majority discussed in the previous section. The latest - and until now - most successful attempt dates from 2014. In 2014, in the above mentioned context of a "return" of the state into local affairs for the purpose of reducing state expenditure and rationalisation, a much more "top-down" approach was followed for dealing with the creation of a metropolitan government. On the one hand, second-tier subnational governments (provinces) were abolished as elected governments; they become administrative entities controlled by municipal representatives. On the other hand, in nine cities (Turin, Milan, Venice, Genoa, Bologna, Florence, Bari, Naples and Reggio Calabria) and in the capital city of Rome, new metropolitan governments have been created by law. They are governed by an elected council and a president and by a conference of all the mayors of the metropolis. Their perimeter follows that of the former corresponding province, which is abolished. In this process of differentiation of subnational governments and of the search for institutional solutions for the government of cities, the government of Rome has also been singled out. In spite of its status as capital, and notwithstanding the fact that the municipality of Rome is far away bigger than any other Italian commune, its government was not previously legally different from any other municipality. An attempt to recognize the specificity linked to the capital status led to an ad hoc law in 1990, which was supposed to provide supplementary financial resources, but it was poorly implemented. 
The municipal executive and the council were thereafter reformed in 2010 and have been equally concerned by the metropolitan reform of 2014 .

The fourth point to be underlined is that, so far, the central state has not vanished. Despite this movement empowering cities, the central state maintains its financial and fiscal functions vis-à-vis city governments. This implies that the state is still responsible for the allocation of relevant resources to subnational governments, but also that austerity policies have had relevant effects on subnational finances. This persistence of the state is also visible when considering relations between central and local governments. On the one hand, the regionalization of the state has led to the consolidation of new intergovernmental relations between each regional government and the sub-regional governments (to which the planning and the implementation of some policies have been delegated). On the other hand, and in a slightly contradictory manner, the increased relevance of city power and of city policies (see below) has kept alive and even reinforced direct relations between city governments and the state. These relations pass through "classical" channels as political parties, through other forms of sectoral and political organizations (for instance, the conservative movement Comunione e Liberazione proves relevant for ensuring vertical ties in some regions, see Tosi \& Vitale, 2011), and through new institutionalized institutional arenas (mainly the conference Stato-Città ed autonomie locali).

To summarize, there has been an evolution from a political system which used to be centralized and in which the "city" was not a specific political unit, to a system in which municipal governments have been strengthened in terms of both their political legitimacy (direct election) and competencies, and in which there is the attempt to create new political and administrative authorities able to tackle with urban challenges (città metropolitane).

\section{Dealing with urban problems}

The unsolved status of the city as a political power and an object of policies in the Italian political system has to be understood not only in relation with the institutional structure but also by focusing on how urban problems have been conceived and addressed by both national and urban governments. The relative empowerment of urban governments discussed above is linked to the emergence of an urban question, intended as a set of initiatives and policies that conceive the city as a specific problem for governments.

The 1950-1980s: "implicit" national policies, municipal innovations and vertical political ties 
After World War II, as is the case in many European countries experiencing in those years an economic boom, major urban problems were linked with the rapid process of urbanization. The latter were boosted by demographic growth and by internal migrations from the countryside toward the city and from the Mezzogiorno toward the northern industrial cities. Cities experienced a new demand for housing and services from new inhabitants. Rapidly growing neighborhoods often lacked basic urban public goods, such as green areas, public transportation or social services.

How was this urban challenge conceived and managed? The creation of the first Ministry for Urban Areas in 1987 provided evidence of the entrance of the urban issue in the national agenda. From the post-war until the late 1980s, therefore, there were no "explicit" national urban policies, intended as cross-cutting policies that target explicitly cities or neighborhoods as particular territories associated with a set of specific issues and policies (Allulli, 2010). More generally, the dominant territorial framework was organized around the North/South cleavage and, beyond this, there was limited formalization of the localized effects of sectoral policies.

However, one cannot argue that, during these decades, there was a total absence of an urban question or of public intervention on cities. Indeed, several pathways for the production of urban policies can be identified. Insofar as state initiatives were concerned, some national policies functioned as "implicit" urban policies. They were conceived and implemented as solutions for the problems generated by steep urbanization. The construction of affordable housing after World War II is an example. From the 1950s until the 1970s (when the last relevant national funding for public housing took place), the central government promoted the construction of residential neighborhoods of affordable housing. Established during the post-war reconstruction period, the Fanfani and Vanoni plans for housing brought together national funding, on the one hand, and the construction of housing based on agreements between municipalities and building cooperatives or firms, on the other. In this respect, the affordable housing policy functioned within the broader context settled by national economic plans, which could be interpreted as a project for the modernization of society drawn up by national elected bodies, but relying strongly on the relation with the social parties and organized interests. Without being plainly spoken of as "urban", some policy sectors worked de facto as urban policies.

A second pathway for the production of urban policies passed through municipal initiatives. As discussed above, in the centralized Italian state suburban governments had limited formal autonomy and capacity for elaborating policies or providing services. Nevertheless, centralization neither meant the absence of urban initiatives nor implied their uniformity across national territories. Municipal governments have adapted, invented and differentiated the management of urban issues. Results have depended on different administrative capacities. Furthermore, political variables were, in many senses, crucial for explaining urban policies. Political parties were the major channel through which local interests were 
represented to the national centre and resources were redistributed from the centre to the locality (Tarrow, 1977; Tarrow, Katzenstein, \& Graziano, 1978). In this respect, the capacity of obtaining resources from the centre was one of the bases on which Christian Democracy built its control in the South (Trigilia, 1992), but this party was also crucial in the vertical mediation in the northern regions of the country characterized by the Christian local political culture (Allum, 1995; Trigilia, 1986). In other cases, political variables functioned by the opposition to the national government. The Italian Communist party which was excluded from governmental coalitions at the central level - developed an urban political offer based on the agenda of increasing the quantity and the quality of public services and of stimulating political participation (Jouve \& Lefèvre, 1996).

From the intersection between vertical ties and local politics, several innovative experiences were born in Italian cities. Urban governments have been important providers of public services in the realm of welfare state policies. At the same time, urban policy making has not been substantially different from Italian policy making in general. It has shared with it the central role occupied by political parties in policy- making and the weak independence of the administration from politicians. It has also shared the propensity for the distribution of benefits, rewarding different publics and clienteles in the policy process, at the expense of a concern with the quality of outputs (Dente, 1990a).

\section{The transformation of urban policies: new coalitions and spaces for policies}

In the context of empowered city governments and the increased responsibilities assigned to the municipal executive that followed the decentralizing project, the modes of production of city policies have been in evolution. Luigi Bobbio has observed a proliferation of contractual practices since 2000, that involve public actors at different levels of government or having different statutes, and include public and private actors (Bobbio, 2000; Cammelli, 2007). Agreements between actors, inducing more flexibility and less hierarchical relations, have become a mainstream tool for organizing relations in the elaboration and the implementation of public policies. For city governments, this has reshaped the conception of the relationship between the public administration and the actors involved in the urban sphere (e.g.: private developers). Contracts have also become one of the privileged manners for getting resources from the central state, in the context of the suppression of the national policy that directly allocated resources sustaining subnational economies and territories (see below).

Some examples illustrate these points. At the scale of patterns of urban development, initiatives and practices of strategic urban planning have multiplied. The first Italian initiative of strategic planning emerged in the city of Turin at the end of the 1990s, inspired by the policy undertaken in Barcelona (Belligni \& Ravazzi, 2013; Pinson, 2002, 2009). Beyond the initial goal of fostering the internationalisation of the city, the two Turin 
strategic plans enlarged their scope to the elaboration of a pattern of development alternative to historical structure of the city as a one company town (Bagnasco, 1986, 1990; for a critical assessment of the results of the plans see Belligni \& Ravazzi, 2013). The Turin experience was soon replicated by Florence, La Spezia, Pesaro, Trento, Venice and Verona and the network of strategic cities included, in 2012, 37 cities (Bussu, 2012). The novelty of strategic planning relies on the fact that these are planning processes aimed at establishing both an interpretation of the present and defining a project of future urban development which is shared by local public and private actors and which can provide the bases for collective action and future public policies (Pinson, 2009). Its legitimacy and strength also depend on the fact that the elaboration process itself is based on participation, discussion and listening among local actors. The work of Gilles Pinson shows that these policies respond to strategies aimed at strengthening the positioning the city in a more competitive economic environment, through the mobilization of local forces (Pinson, 2009). They therefore differ from historical activities of urban governments related to the control of land and the provision of basic services.

The meaning of urban planning policies has partly been redefined by these changes, following a trend that is far from being a national specificity. On the one hand, the physical transformation of the urban space has been increasingly linked to attempts to affirm new economic or cultural activities, international positioning, or to construct new representations of the city. Big events have constituted a temporal and financial policy opportunity window for the transformation of Italian cities. The requalification of the existing built environment or the building of new flagship projects and infrastructures have been anchored to specific events, such as the Colombiadi in Genoa, the Winter Olympics in Turin or the Jubilee in Rome. Such events bring substantial extra-resources to the local administration from the state, hence ensuring their popularity among urban elites. On the other hand, a general process of deregulation of planning policies has favored the regeneration of disused lands and buildings through large-scale redevelopment projects. These transformations of brownfield sites have often taken place by side-lining or substantially transforming the recommendations of the regulatory urban plan. Cities have been transformed "project by project", through ad hoc regulatory arrangements targeting specific areas (Dente, 1990b). These projects have contributed to marginalizing - in practice as much as in the policy rhetoric - the Italian conception of the urban plan as a powerful instrument capable of orienting the spatial development of the city as a whole. In addition, they have in many cases favoured the real estate sector (Amato, Bolocan, Cremaschi, Governa, \& Pasqui, 2011, p. 255; Anselmi, 2015) and been based upon privileged relations between the municipal governments and a small number of developers (Cremaschi, 2010).

The last decades have also witnessed the proliferation of area-based policies. A set of initiatives - called Complex Urban Programs - arose in the 1990s with the objective of acting 
on the city through a "new" localized and inter-sectorial approach ${ }^{2}$ (Crosta, 1998; Bricocoli \& Cementeri, 2005; Vicari Haddock, 2005; Governa \& Salone, 2004). The case of "neighborhood contracts" provides a good example of these complex urban programs. The programme was launched by the Ministry of Public Works in 1997, in a broader context of reforms decentralizing and "contractualizing" national social policies. Here, contracts seek the "urban and social requalification" of affordable housing neighborhoods, affected by both the physical degradation of the built environment and a high concentration of social problems. In this program, the neighborhood becomes, at the same time, the location and the object of new intersections between different policy sectors, first and foremost social policy, urban planning and housing policy. In the Italian policy landscape, taking a particular urban space - here, a neighborhood - as an object of inter- sectoral intervention constitutes a change from the dominant policy approach that either targeted specific groups, or adopted a standardised framework. Moreover, the identification of policy actions is tied to the principle of the involvement of local actors. Local involvement is justified in terms of designing policies that fit the specific needs of each context; it is also a condition for allowing territories to compete for the scarce resources (either national or European) necessary to finance and implement projects.

\section{The new policies driven by the European Union and city governments}

What is the political configuration underpinning these transformations of coalitions and spaces of urban policies? From a bottom-up perspective, the evolution of urban policies cannot be understood without taking into account the transformation of urban political leadership brought by both the decentralization process and by the reform of the local electoral system mentioned above. Mayoral positions in big cities have become more visible and relevant in Italian politics. The office of mayor has become one of the possible trampolines for entering national politics. In addition, the first directly elected mayors were, to some extent, "outsiders", distinct from (and often opposed to) the classical political elites. To provide some examples from the biggest Italian cities, in Turin, Valentino Castellani, elected mayor in 1993, was a university professor and not a professional politician ${ }^{3}$. At the same moment, in Milan, the city where the national Tangentopoli scandal about widespread briberies in the political system started, the new mayor Marco Formentini was an unknown member of the Northern League. The unprecedentedly strong results of its party swept away the traditional parties in power in Milan. In Rome, finally, a professional politician was elected as mayor, but he came from the political margins, a member first of the Radical Party and later of the Green Party. The mayoral role has expanded greatly since the early 1990s: today's mayors play a central role in aggregating interests, mobilizing actors who control resources that can be mobilized for local policy-making (private companies,

\footnotetext{
${ }^{2}$ Major programs are: Programmi Integrati di Intervento (1992), Programmi di Recupero Urbano (1993), Programmi di Riqualificazione Urbana e Sviluppo Sostenibile del Territorio (1994) and Contratti di Quartiere (1997) and the Italian implementation of the URBAN Program of the European Union.

${ }^{3}$ In Italy, a mayor cannot stay in power for more than two consecutive mandates. Valentino Castellani has been elected from 1993 to 1997 and again from 1997 to 2001.
} 
universities and local elites) and solving conflicts.

From the top-down perspective, the process of Europeanisation has also played a crucial role. A prominent example is the URBAN Community Initiative that started in 1994 and had a direct effect on Italian city policies (Palermo, 2002). The Initiative received a quite enthusiastic response in the country and has been widely appropriated by city governments, since 16 cities participated in the first round (12 of which were in the South) and a dozen to the second. More generally, area-based and contractual policies were directly inspired by foreign urban experiences. For instance, policies for peripheral neighbourhoods of the mid1990s were inspired from British and French policies that, ten years before, had constructed this issue as a specific policy problem. The French Politique de la Ville, for instance, was used as a model for the elaboration of the Italian Neighbourhood Contracts, Urban Free Zones and Local Security Pacts. The regions, drawing on European funding, have also played a role in organizing city policies. In the process of regionalization from the 1990s onward, the management of European funds - including the urban programs - contributed to the development of regional administrative capacities. At the same time, regional governments have used their responsibilities in the management of European funds for strengthening their control over the action of city governments, through the definition of the criteria for obtaining grants.

On the other hand, a national strategy or integrated policy for cities has not emerged, in spite of a first attempt. The urban issue was labelled as such and recognised as part of the national political agenda in 1987, through the creation of a ministry for Urban Areas. However, the ministry had much more limited responsibilities for urban areas than foreseen (Allulli \& Tortorella, 2013), and it was abolished a few years later in the context of the political crisis. The way the central state has dealt with urban issues has, therefore, been more variegated and sector-based than the creation of a dedicated ministry would have led one to expect. Some "implicit" policies have lost their relevance (for instance, the above mentioned housing policy). The way state policies address the problems of regional development has changed, which has also had consequences for cities. Until the 1970s, national policies focused on redistributive issues and on the direct sustaining of economic development. Along with the reduction in State resources and the limitation on economic interventionism introduced by European Union, a new ethos has underpinned national territorial policies, based on the competitive allocation of resources. Such policies have also become oriented towards promoting the mobilization of local actors (Magnatti, Ramella, Trigilia, \& Viesti, 2005; Perulli, 2010; Ramella, 2010). Yet, state intervention has been relevant in setting the regulatory framework enabling policies (for instance, the introduction of contractual agreements as a tool for administrative action), in defining the framework for the implementation of EU policies and also in redefining quite substantially the distribution of power among levels of governments (I). In addition, the state has participated in institutionalizing and proceduralizing city government initiatives. For instance, if strategic planning was first and foremost initiated by city governments, central government administrations (CIPE) have been promoting strategic planning in the South, also in 
conjunction with the management of European structural funds.

\section{When Italian cities change without and beyond policies}

In the meanwhile, Italian cities have changed. A number of structural changes affecting Italian cities - industrialization and change of employment sectors, population aging and the arrival of immigrants - are similar to those in other European cities.

\section{$\underline{\text { Policies for some problems, problems without policies }}$}

Sometimes, Italian cities have changed without policies, while old and new problems have been partially or poorly addressed by those policies adopted. At the beginning of the 1990s, the problems on mayors' desks were becoming more complex. On the one hand, in many cities and neighbourhoods, the demand for basic urban services and goods is still a relevant issue (Amato et al., 2011). On the other hand, municipal governments are confronted with a new series of questions that have arisen during the 1980, which are still being addressed. Generally speaking, these issues are connected with the "redefinition of the model of urban development" of cities (Amato et al., 2011, pp. 208 - 209). This implies sustaining the productive metamorphosis of the city (more particularly in the more industrial and Fordist cities whose economies are restructuring), dealing with its physical transformation, strengthening research and education, building shared infrastructure for local economic activities and reinforcing cultural activities. During the 2000-10 decade, Italian city governments started to address other themes and proposed new public policies in fields such as urban "security" (Allulli, 2010). The issue of "competitiveness" has also been widely diffused, which has partially overlapped with that of the transformation of urban patterns of development.

Not everything has been governed, however. Some issues have not made it onto the political agenda, while others have been addressed in a partial manner. The government of economic processes can be taken as an example. Economic change and the transformation of the productive systems of cities have been addressed in quite different ways. Considering the main four metropolitan areas of the country (Milan, Rome, Naples and Turin), some authors establish a distinction between the cases of Milan and Naples and the cases of Rome and Turin (Amato et al., 2011, p. 222). In the first two cases, several changes and economic initiatives have happened despite or beyond public policies. The transition of Milan from an industrial to a post-fordist city, for instance, has been more the fact of initiatives undertaken by social and economic actors than the conscious design of public authorities. Indeed, several relevant projects - such as the new university campus or the creation of medical facilities - have been realized through the mobilization of private resources or autonomous semi-public stakeholders, banks and banking foundations, with low involvement from local 
government (Dente, Bobbio, \& Spada, 2005). On the contrary, in Turin and Naples, policies have played a more relevant role in accompanying economic change and innovation. One recent study of Turin defends the idea that a governance coalition between the city government and private actors has contributed to the implementation of an agenda which has been rather stable over the last twenty years. Though this has not led to a complete reorientation of the historical pattern of development of the city, the public-private coalition has been effective in some of policy-sectors, especially large-scale infrastructures, leisure and tourism (Belligni \& Ravazzi, 2013).

The involvement of city governments in local development policies is therefore variegated, as are the results of local policies. The differentiation of both policies and outputs does not entirely cover the "classic" North/South divide. One collective research project on how Italian cities build and promote local development has brought a different perspective on the classic territorial division, based on macro-regional oppositions (Casavola \& Trigilia, 2012). Indeed, analysing local resources for development - cultural and environmental goods, scientific knowledge, diffuse knowledge and know- how - (Casavola \& Trigilia, 2012) demonstrate that cities in Southern Italy do not have fewer resources than cities in the North. They differ, however, in their capacity to recognize, activate and strengthen these resources through adopting public policies and engaging in collective action. In other terms, in Italian cities there are resources for development, but they are more or less activated by collective action.

\section{The limits of urban governmental action}

Despite a long-term trend seeking to strengthen both urban political authorities and the relevance of the urban question as a specific policy problem, urban Italian policies have experienced and still experience problems of coordination, effectiveness, resources and legitimacy.

After fifteen years, contractual urban policy making has started to lost steam and has become the object of increasing criticisms. Mismanagement of the implementation of policy programs and of the use of European funds has been highlighted. Policies have produced unequal results and their degrees of completion are variable. The difficulty in establishing organizational and coordination capacities in the long run has also become apparent. The URBAN program, for instance, has produced relevant results in the requalification of central areas and in promoting and preserving the historical and artistic patrimony of several cities. However, once EU credits have been consumed by the program, it has been difficult to keep collective action on the rails, both in terms of ensuring policy coordination and establishing collaboration for local development with private actors (Casavola \& Trigilia, 2012, p. 363). From another perspective, the idea of local based action as a comprehensive solution for local problems has also been challenged. National, regional and international processes have 
had strong effects that area based approaches are unable to tackle in their entirety. The identification of the locality as both a problem and the starting point of its solutions has lost part of its legitimacy (Vicari Haddock, 2005).

Beyond specific policies, financial resources have also been a problem for Italian city governments. During the last 30 years, State transfers have been reduced and the long-term trend has been for the increase of local financial responsibilities. However, the last few years have been characterized by a reverse trend, as a result of the suppression of the local property tax that benefited municipal budgets in 2008, and which has been re-introduced only recently and is still the object of strong controversy (Perulli, 2013). Moreover, central government constraints and controls on municipalities have expanded, as a consequence of the adoption of the Internal Stability pact in 1999, which is a derivation from the Stability and Growth Pact at the European level. Aimed at sharing the effort at public deficit reduction across all levels of governments, it has had a crucial role in defining regional and local finances by setting thresholds for both deficits and expenditure. In addition, analysis of the 2008 crisis reveals that it has been mainly managed with straight cutback management (Di Mascio \& Natalini, 2014).

The curtailing of local resources has had several consequences for cities. The most direct effect concerns the reduction of spending, both in terms of current and investment expenditures. Between 2009 and 2011, municipal government overall expenditure has declined and, within this, investment expenditure has decreased by $9 \%$ (Corte dei Conti, 2012). There has been a lack of modernization and renewal of existing infrastructures, but also difficulties in ensuring the delivery of standard municipal services. Furthermore, a more indirect and unexpected effect of the lack of resources can be pointed out. It concerns the transformation of the urban space and the real estate sector. Indeed, the taxes perceived by the municipalities for new urban developments have been allowed to cover not only investment but also current expenditures. This supplementary fiscal resource has become a routine source of income for local authorities, with the consequence that the functioning of the local administration and the services it provides are partly ensured by the permanent growth of the built environment (Bellicini, 2011; Tosi \& Vitale, 2011). This has incited municipalities to allow property developments as a budgetary response, beyond any consideration of the effects of this process for urban sprawl, transportation policies and social cohesion (Tosi \& Vitale, 2011).

The legitimacy of Italian Mayors has also declined, as the limits of local government action have become apparent. Indeed, some researchers highlight the mismatch between the semipresidential function of the mayor and the expectations that it raises, on the one hand, and its effective capacities of action, on the other. Others focus on what is considered as a general inertia of urban political agendas (Amato et al., 2011), which are considered as having insufficiently evolved during the last two decades. Still others focus on the difficulties that city governments encounter when they attempt to coordinate sectoral actors. 
Actors, both private and public, that operate at supralocal level tend to escape local control. Even within the public sector, there is a weak capacity to coordinate sectors whose competences are linked to upper tiers of government (Artioli, 2014), or alternatively this coordination relies on organized interests having strong vertical ties (Tosi \& Vitale, 2011).

Furthermore, the central government has also been criticized for being unable to sustain and evaluate local initiatives (Perulli, 2010). There is the enduring claim about the lack of a national project for Italian cities. This lack of national steering is due not only to problems in setting goals or coordinating different sectoral and territorial interests, but also to a poor understanding of the territorial (and urban) dimension of national policies, including the infrastructural ones. Some authors talk about "unknown Italian cities" and about a "cognitive lock-in" (Calafati, 2014, p. 9) that tends to privilege a focus on macro-regional performances or on industrial districts, without considering cities as part of the national territorial question (Calafati, 2014, p. 9).

\section{Conclusion}

The chapter has tracked the evolution of cities as objects for policies and as political actors in the Italian political system. By focusing on both formal authorities and policy elaboration/implementation, it has showed a process of change in the Italian urban issue. This can be identified as a double dynamic of delegation of responsibilities from the centre to the city government level and of identification of urban issues as specific policy problems.

However, this double dynamic is characterized by tensions. First, there are tensions between levels of government. Central government and local authorities are both confronted with the problem of how to manage reduced public resources, which increases conflicts. In addition, there is a lack of clarity across levels of government about shared goals for Italian city development. The organization of multilevel relations is also ambiguous. Neither central not local government has a consistent view about how best to represent the interests of cities vis-à-vis the upper levels of governments (state and region).

Secondly, tensions come from the weak capacity of governments to effectively govern social and economic processes and problems in Italian cities. This refers to the issues of giving an orientation to exogenous processes and change, of coordinating contrasting sectoral interests and groups and, more generally of giving a response to both persistent problems in everyday service provision and new policy challenges. Indeed, while some issues are addressed, others are constantly left aside from policy agendas, and others are governed in partial manners. 
These tensions at both the national and the urban levels allow qualifying the unsolved character of the urban question in contemporary Italy. Three explanatory hypotheses can be pointed out in the conclusion, and they call for further research. First, this situation might be interpreted as the consequence of poor policy choices. Statements like "cities in search of a policy" (Allulli \& Tortorella, 2013) or "economies in search of cities" (Calafati, 2009) refer to the idea that existing policies fail to understand and mismatch the transformation of urban economies and societies. Secondly, it might also be conceived as the result of resistance from specific groups and territories that, in the Italian political system and hence also in cities, escape from or oppose the reach of government (Cassese, 2014). Finally, it can be understood by considering that in a context of conflicting interests, both political and territorial, a status of permanent transitory solutions is a stronger outcome than a stabilized system, as it provides governmental bodies with broader discretion, room for innovation and blurred accountability.

\section{References}

Aimo, P. (1997), Stato e poteri locali in Italia: 1848-1995 (Storia), Roma: Carocci.

Allulli, M. (2010). Le politiche urbane in Italia. Tra adattamento e frammentazione. Roma: CITTALIA.

Allulli, M., \& Tortorella, W. (2013). Cities in search of Policy. Métropoles, (12). Retrieved September 11, 2015, from http://metropoles.revues.org/4654

Allum, P. (1995). Le double visage de la Démocratie chrétienne. Politix, 8(30), pp. 24-44.

Amato, Fabio, Bolocan, Matteo, Cremaschi, Marco, Governa, Francesca, \& Pasqui, Gabriele. (2011). Torino, Milano, Roma, Napoli. Ciclo politico, agenda urbana, policies, in: Le grandi città italiane. Società e territori da ricomporre, pp. 207 - 270. Venezia: Marsilio.

Amoretti U M, 2004, "Italy. Political Institutions and the Mobilizations of Territorial Differences", in Federalism and Territorial Cleavages Eds Ugo Amoretti and Nancy Bermeo (Johns Hopkins University Press, Baltimore), pp 181 - 197

Anselmi, Guido. (2015). I Megaprogetti immobiliari nell'epoca di finanziarizzazione e austerity: $i$ casi di Milano e Salford, Tesi di Dottorato in Studi Europei Urbani e Locali, Università Milano Bicocca.

Artioli, Francesca (2014). L'armée, les villes, l'État. Restructurations militaires et politiques urbaines : les transformations de l'intégration territoriale en France et en Italie. Thèse de Science Politique, Institut d'Etudes Politiques de Paris.

Bagnasco, Arnaldo (1986). Torino. Un profilo sociologico. Torino: Einaudi.

Bagnasco, Arnaldo (1990). La Città dopo Ford: il caso di Torino. Torino: Bollati Boringhieri.

Baldini, Gianfranco (2007). Sistemi politici locali e modello neoparlamentare: istituzioni, leadership e stabilità nelle città italiane (1993 - 2005), in: Marco Cammelli (Ed.), Territorialità e delocalizzazione nel governo locale, pp. 665 - 680. Bologna: Il mulino.

Bellicini, Lorenzo (2011). Immobiliare, debito, città, in: Le grandi città italiane. Società e territori da ricomporre, pp. 77 - 115. Venezia: Marsilio.

Belligni, S., \& Ravazzi, S. (2013). Policy change without metamorphosis. The 1993-2011 urban regime in Turin. Métropoles, (12). Retrieved September 11, 2015, from http://metropoles.revues.org/4642

Bobbio, L. (2000). Produzione di politiche a mezzo di contratti nella pubblica amministrazione italiana. Stato e mercato, (1), pp. 111-142. 
Bolgherini, S. (2014). Can Austerity Lead to Recentralisation? Italian Local Government during the Economic Crisis. South European Society and Politics, 19(2), pp. 193-214.

Bricocoli, Marco, \& Cementeri, Luisa (2005). Abitare: tra l'alloggio e la città. Quando le politiche entrano in casa, in: Le nuove politiche sociali. Problemi dell'azione pubblica. Roma: Carocci.

Brunazzo, Marco (2010). Italian Regionalism: A Semi-Federation is Taking Shape - Or is It?, in: Harald Baldersheim \& Lawrence E. Rose (Eds.), Territorial choice: the politics of boundaries and borders, pp. 185 - 197. New York: Palgrave Macmillan.

Bussu, Alice (2012). Governing with the citizens. Strategic Planning in Four Italian Cities, PhD Thesis, London School of Economics and Political Science.

Calafati, A. (2014). The Changing Italian Cities: Emerging Imbalances and Conflicts. GSSI Urban Studies Working Papers, (6). Retrieved August 6, 2015, from http://papers.ssrn.com/abstract=2494225

Calafati, Antonio. G. (2009). Economie in cerca di città: la questione urbana in Italia. Donzelli Editore.

Cammelli, Marco (2007). Territorialità e delocalizzazione nel governo locale. Bologna: Il mulino. Casavola, Paola, \& Trigilia, Carlo (Eds.). (2012). La nuova occasione. Città e valorizzazione delle risorse locali. Roma: Donzelli.

Cassese, Sabino (2014). Governare gli italiani. Storia dello Stato. Bologna: Il Mulino.

Corte dei Conti. (2012). Relazione sulla gestione finanziaria degli enti locali. Roma: CdC.

Cremaschi, M. (2010). Rendita fondiaria e sviluppo urbano nella riqualificazione urbana: per un'ipotesi interpretativa. Società Italiana di Scienza Politica, XXIV Convegno, pp. 1-19.

Crosta, Pierluigi (1998). Politiche. Quale conoscenza per l'azione territoriale. Milano: Franco Angeli.

Dente, Bruno (1990a). Le politiche pubbliche in Italia. Bologna: Il Mulino.

Dente, Bruno (1990b). Metropoli per Progetti: Attori E Processi Di Trasformazione Urbana a Firenze, Torino, Milano. Bologna: Il Mulino. Retrieved May 16, 2010,

Dente, B. (2012). The end of an era? The Monti government approach to central-local relations. LIEPP Working Papers, (6), pp. 1-21.

Dente, B., Bobbio, L., \& Spada, A. (2005). Government or Governance of Urban Innovation?

disP - The Planning Review, 41(162), pp. 41-52.

Le Galès, P., \& Vitale, T. (2013). Governing the large metropolis A research agenda. Working papers du Programme Villes \& Territoires, 8, pp. 1 - 20.

Governa, F., \& Salone, C. (2004). Territories in action, territories for action: the territorial dimension of Italian local development policies. International Journal of Urban and Regional Research, 28(4), pp. 796-818.

Jouve, B., \& Lefèvre, C. (1996). Dynamique institutionnelle et culture politique territoriale : la cité métropolitaine de Bologne. Revue française de sociologie, 37(3), pp. 369-396.

Lippi, A. (2011). Evaluating the "Quasi Federalist" Programme of Decentralisation in Italy since the 1990s: A Side-effect Approach. Local Government Studies, 37(5), pp. 495-516.

Lippi, A. (2015). «A laboratory for the disorder?» Never-ending de-centering and re-centering in intergovernmental relations in the Italian case. International Conference on Public Policy, Milan, July 1-4 2015, pp. 1-24.

Magnatti, Piera, Ramella, Francesco, Trigilia, Carlo, \& Viesti, Gianfranco (2005). Patti territoriali: lezioni per lo sviluppo. Bologna: Il Mulino.

Di Mascio, F., \& Natalini, A. (2014). Austerity and Public Administration Italy Between Modernization and Spending Cuts. American Behavioral Scientist, 58(12), pp. 1634- 1656.

Page, Ed C., \& Goldsmith, Michael J. (1987). Central and Local Government Relations: A Comparative Analysis of West European Unitary States. Oxford: SAGE Publications.

Palermo, Pier Carlo (Ed.). (2002). Il programma Urban e l'innovazione delle politiche urbane. Il senso dell'esperienza: interpretazioni e proposte. Roma: MIITT. 
Perulli, P. (2010). Politiche locali tra decentralizzazione e ricentralizzazione. Stato e mercato, (3), pp. 365-374.

Perulli, P. (2013). Return of the State and attempts of centralisation in Italy. Métropoles, (12).

Retrieved September 14, 2015, from http://metropoles.revues.org/4665

Piattoni, Serena, \& Brunazzo, Marco (2010). Italy: The Subnational Dimension to Strengthening Democracy Since the 1990s, in: Oxford Handbooks Online. Oxford. Retrieved from http://www.oxfordhandbooks.com/view/10.1093/oxfordhb/9780199562978.001.000 1/oxfordhb9780199562978-e-15.

Pinson, G. (2002). Political Goverment and Governace : Strategic Reshaping of Political Capacity in Turin. International Journal of Urban and Regional Research, 26(3), pp. 477-493.

Pinson, Gilles (2009). Gouverner la ville par projet : Urbanisme et gouvernance des villes européennes. Paris: Les Presses de Sciences Po.

Pinson G, Galimberti D, Lefèvre C, 2013, “Territoires, villes et métropoles en Italie. Présentation du numéro spécial" Métropoles (12), https://metropoles.revues.org/4641

Ramella, F. (2010). Negotiating local development: the Italian experience of "Territorial Pacts."

Environment and Planning C: Government and Policy, 28(3), pp. 512 - 527.

Romanelli, Raffaele (1995). Storia dello Stato italiano dall'Unità a oggi. Roma: Donzelli Editore.

Tarrow, Sidney G. (1977). Between center and periphery. Grassroots politicians in Italy and France. New Haven: Yale University Press.

Tarrow, Sideny G., Katzenstein, Peter J., \& Graziano, Luigi (1978). Territorial politics in industrial nations. New York: Praeger.

Tosi, Simone, \& Vitale, Tommaso (2011). Piccolo Nord. Scelte pubbliche e interessi privati nell'Alto Milanese. Milano: Bruno Mondadori.

Trigilia, Carlo (1986). Grandi partiti e piccole imprese: comunisti e democristiani nelle regioni a economia diffusa. Bologna: Il Mulino.

Trigilia, Carlo (1992). Sviluppo senza autonomia. Effetti perversi delle politiche nel Mezzogiorno.

Bologna: Il Mulino.

Vandelli, Luciano (1997). Sindaci e miti: Sisifo, Tantalo e Damocle nell'amministrazione locale (Contemporanea). Bologna: Il mulino.

Vandelli, Luciano (2013). Il sistema delle autonomie locali. Bologna: Il Mulino.

Vicari Haddock, Serena (2005). La rigenerazione urbana: frammentazioni e integrazioni, in: Le nuove politiche sociali. Problemi dell'azione pubblica. Roma: Carocci. 